\title{
Novel Integration of Geopolymer Pavers, Silva Cells and Poplar Trees for In-Situ Treatment of Car-Wash Wastewater
}

\author{
Rishi Gupta ${ }^{1}{ }^{1}$, Neeta Raj Sharma ${ }^{2}$, Caterina Valeo ${ }^{3}{ }^{\oplus}$, Mohit Garg ${ }^{1}{ }^{\oplus}$, Ashutosh Sharma ${ }^{1}$, \\ Sakshi Aneja ${ }^{1, *}$, Shiv O. Prasher ${ }^{4}$ and C. Peter Constabel ${ }^{5}$ \\ 1 Department of Civil Engineering, University of Victoria, Victoria, BC V8W2Y2, Canada; \\ guptar@uvic.ca (R.G.); mgarg@uvic.ca (M.G.); rasharma86@uvic.ca (A.S.) \\ 2 School of Bioengineering and Biosciences, Lovely Professional University, Phagwara 144411, Punjab, India; \\ neeta.raj@lpu.co.in \\ 3 Department of Mechanical Engineering, University of Victoria, Victoria, BC V8W2Y2, Canada; valeo@uvic.ca \\ 4 Department of Bioresource Engineering, McGill University, Ste-Anne-de-Bellevue H9×3V9, \\ Montréal, QC H3A0G4, Canada; shiv.prasher@mcgill.ca \\ 5 Centre for Forest Biology and Department of Biology, University of Victoria, Victoria, BC V8W2Y2, Canada; \\ cpc@uvic.ca \\ * Correspondence: sakshianeja@uvic.ca
}

Received: 16 September 2020; Accepted: 12 October 2020; Published: 14 October 2020

\begin{abstract}
This paper presents an eco-friendly, low-impact development (LID) approach, developed and implemented at a car wash site for a cleaner and greener environment. In this approach, the contaminated water discharged after car washing is treated as it is directed through an engineered, ecology-based water-management design. The design involves poplar (Populus deltoides) trees, Silva Cells ${ }^{\circledR}$, and Fly-ash based Geopolymer concrete pavers working collectively to minimize the percolation of contaminants into the soil. In this novel system, each component has a vital role. For instance, the extensive roots of the poplar trees enable water filtration owing to phytoremediation effect; while the Silva Cells ${ }^{\circledR}$ promote stormwater management, planting of poplar trees and serve as a foundation for paver blocks. Lastly, the paver blocks made from industrial waste allow it to withstand urban load and infiltrate water runoff, thereby reducing runoff quantities. To evaluate the efficacy of contaminant uptake by this system, $\mathrm{pH}$, electrical conductivity and turbidity, which are indicators of water quality levels, were monitored pre- and post-treatment. The percentage change in total dissolved solids indicates the potential of this treatment system for effective treatment of the contaminated car wash water.
\end{abstract}

Keywords: wastewater; permeable pavement; bioretention; low-impact development; Silva Cells ${ }^{\circledR}$; geopolymer concrete; poplar trees

\section{Introduction}

Rapid urbanization and industrialization are constantly challenging the sustainable growth of our society. As a result, the natural resources of water, land, vegetation and animal life are greatly impacted [1,2]. Water sustains all forms of life on earth and blankets $71 \%$ of earth's surface out of which only $2.5 \%$ is fresh water. Despite having the largest water footprint and with a blue water footprint of 243 billion cubic meter (BCM)/year, water shortages to cater the demands of multiple sectors such as manufacturing industry, agriculture, household, electricity and gas are predicted in the near future [3,4]. An expeditious shift from an agriculture-based economy to an industrial-based economy has greatly stressed India's water demand [5]. The availability of fresh water in India has been further affected 
by the release of toxic industrial wastes and dumping of effluents into water bodies; thus, causing water pollution issues. Quantitatively, approximately 40 million L of wastewater enters the rivers and other bodies on a daily basis [6]. However, only a very small fraction of this wastewater gets treated. As a result, India has incurred approximately 5-6 billion dollars in health-related costs from 2009-2010, and roughly 400,000 lives are lost due to the spread of diseases through water bodies [7]. Generally, the most commonly used treatment technologies involve coagulation, foam floatation, filtration, solvent extraction, adsorption, flocculation, sedimentation, demineralization and have their own limitations [8-12]. Further, these waste water treatment facilities are expensive involving a dense network of underground pipes requiring larger areas [13]. To address this sporadic concern and the growing inadequacy of conventional methods to treat wastewater, researchers have recently started to focus on investigating smart alternatives or integrated technologies to combat this issue nationally as well as globally.

The development of Low impact development (LID) technologies that could utilize phytoremediation $[14,15]$ (a process to improve water quality by plants by extracting or stabilizing the contaminants) is underway across the globe. Trees and woody plants are considered superior for phytoremediation due to their large biomass and extensive root systems [14] which makes them ideal for extracting minerals from soil. Both macronutrients and micronutrients are absorbed by roots over large concentration ranges. Metals (micronutrients) such as copper and zinc are required by plants at low levels but other metals such as cadmium and arsenic, are not used by plants, but are nevertheless taken up by plants as they grow and develop [16]. However, one of the issues for using phytoremediation for removing impurities such as suspended solids, phosphorous and nitrogen from waste water remains the improper choice of the vegetation [17]. These challenges are further expanded in the absence of a multidisciplinary approach for developing sustainable solutions.

In 2018, researchers had conducted a preliminary study in Canada and proposed a novel interdisciplinary strategy for treating urban wastewater [18]. This work focused on treating wastewater through double filtration technology, i.e., (i) The primary filtration was provided by a stable-permeable surface prepared by an environmentally safe material; (ii) the secondary filtration was achieved by the process of phytoremediation, via extensive rooting system of trees. The stable surface was created by installing a series of Silva Cells ${ }^{\circledR}$ upon which cement-free porous Geopolymerised pavers were placed. The paving blocks were laid on a layer aggregates that had a maximum size of $12 \mathrm{~mm}$.

Normally, the paver blocks are widely used in India, they provide a significant lifespan with regards to their pervious behavior. The sustainable part of using them is that they are made of a waste material and since they are simply laid over the ground, they can easily be removed to clear any clogging that might take place over time. It should be noted that pavers allow for the wastewater to infiltrate through the joints of the pavers. The pavers themselves are not designed to be permeable. Depending on the load of sediments in the runoff, the joints between the pavers will get clogged. The usual maintenance protocol calls for power washing the joints annually.

To achieve the secondary filtration, a series of poplar trees were planted into the designated space in Silva Cells ${ }^{\circledR}$. These trees were chosen owing to their extensive and deep rooting system into the soil and their high-water usage. The wastewater flows through the permeable surface as it undergoes primary filtration, and then the remaining impurities in the water are absorbed by the roots of poplar trees. The proposed methodology was based on a low-impact development approach for wastewater treatment most suited for remote and rural locations including developing countries like India. This study continues to illustrate the outcome of adopting LID methodologies as a potential smart city method that addresses the concerns of water contamination at a site chosen in India.

Various potential polluted sites of interest in India were considered (i) nut and washer manufacturers; (ii) muddy waste collection areas adjacent to steel industries; (iii) car washing service stations. Several soil and water contamination tests were conducted on the three sites to identify a suitable site for the LID system deployment. Water contamination at car wash stations is quite prevalent due to the discharge of harmful car cleaning detergents, as well as heavy metals and 
hydrocarbons during car washing into the drainage water and surrounding soil. Therefore, the car wash station site seemed to be a good fit for remediation as well as sustaining urban infrastructure amongst various options. The team then conducted a survey of local car wash stations in the state of Punjab, India. The findings indicated a wide disparity in the types of wash water treatment systems being practiced. At one extreme, a car wash station enveloped a sophisticated system that fully treated and reused the wastewater [19]. On the other end of the spectrum, car wash sites did not have any process to treat the wastewater. The untreated wastewater simply joined surface runoff or groundwater after contaminating several hundred square feet of ground surface. Initially, soil samples were collected from the car wash site to analyze the presence of microbial populations that would assist in degrading hydrocarbons released from cars. Comparing the weight of crude oil recovered from the medium showed that there was no significant degradation of oil by microbes isolated from the car wash site. Hence, the latter type of car wash stations where no treatment was being practiced, motivated the work presented in this paper, and resulted in this novel study. Hence, the objective of this paper is to evaluate the efficacy for decontaminating water discharged after a car wash using the proposed in-situ eco-friendly system.

\section{Methodology}

The novel, in-situ, efficient and environment friendly wastewater treatment system primarily constitutes of the following:

1. Silva Cells ${ }^{\circledR}$;

2. Fly-ash based Geopolymer concrete pavers;

3. Populus detoides (P. deltoides) trees in soil media;

4. In-situ sensors with data collection system.

Silva Cells ${ }^{\circledR}$ are recognized as modular building blocks that have dual capabilities-facilitating plant growth and stormwater management. Silva Cells ${ }^{\circledR}$ procured from DeepRoot Corporation, Canada included a base, deck, and $2 \times$ posts that had dimensions of $600 \times 1200 \times 784 \mathrm{~mm}$.

Geopolymer concrete (GC) pavers developed by eliminating the use of Portland cement, served dual benefits: a step towards sustainable or eco-friendly approach, and secondly to allow full precipitation infiltration during the rainy season. The unique manufacturing process of these GC pavers includes using fly-ash and bottom ash, collected from waste produced in thermal power plants, then mixing it with sodium, Na-based polymers and curing at a higher temperature to attain strength and desired durability. The detailed process of producing GC pavers as well as their utility in real-applications can be found in [20-22]. Based on these findings [20-22], trial batches of Na-based Geopolymer concrete paver blocks (with mold of $150 \times 150 \times 100 \mathrm{~mm}$ ) were manufactured and cured at $80^{\circ} \mathrm{C}$, at Lovely Professional University, India. The strong and durable pavers obtained from the lab allowed the researchers to purchase 400 fly-ash based paver blocks casted in a commercial facility.

$P$. deltoides were procured from an agricultural farm, and then planted at designated tree spaces in the layout of Silva Cells ${ }^{\circledR}$. The rationale to choose these special plant species were: easier availability locally, promising uptake of benzene/toluene/ethylbenzene/xylene compounds [23], petroleum hydrocarbons [24], as well as solid waste landfill leachate [25]. The extensive root system of these plant species utilizes phytoremediation for the initial uptake of pollutants/heavy metals, and eventually accumulating them onto the leaves by translocating across the stem. A special phytoremediation method that relates directly to the absorption of contaminants from surface wastewater by plant roots and preventing it from leaching into the soil/underground water is referred to as phytofiltration, which has been applied in the present study.

Sensors were deployed on the site for real-time monitoring of water quality both pre- and post-treatment. The working temperature of the site varied between 10 and $40^{\circ} \mathrm{C}$. Lastly, the important step included analysis of the data collected from the sensors. The data included physico-chemical parameters of normal tap water (as a baseline), inflow as well as outflow of water through the Silva 
Cells ${ }^{\circledR}$ by taking water samples over a period of time. Tables 1 and 2 lists the specifications of WIFI remote monitoring system HOBO RX3002 (TRANSCAT make) and pH, turbidity and electrical conductivity) sensors, used in the study that were procured from Hoskin Scientific, Canada. It is important to note that the data was recorded remotely and accessed using a web-based server.

Table 1. Specifications of Data Acquisition System.

\begin{tabular}{cc}
\hline Model & HOBO RX3002 Wi-Fi \\
\hline Operating Range & $-40^{\circ}$ to $60^{\circ} \mathrm{C}$ \\
\hline Module Slots & 2 \\
\hline Logging Rate & $1 \mathrm{~s}$ \\
\hline Battery Type & $4 \mathrm{~V}, 10 \mathrm{AHr}$, rechargeable sealed lead-acid \\
\hline Memory & $32 \mathrm{MB}$ \\
\hline LCD & LCD is visible from $0^{\circ}$ to $50^{\circ} \mathrm{C}$ \\
\hline Size & $18.6 \times 18.1 \times 11.8 \mathrm{~cm}$ \\
\hline Weight & $2.2 \mathrm{~kg}$ \\
\hline
\end{tabular}

Table 2. Specifications of $\mathrm{pH}$, turbidity and electrical conductivity sensors.

\begin{tabular}{|c|c|c|c|}
\hline Sensor & $\mathrm{pH}$ & Turbidity & Conductivity \\
\hline Range & $0-14 \mathrm{pH}$ & 0-50NTU, 0-1000NTU & 200-2000 $\mu \mathrm{S} / \mathrm{cm}, 2-20 \mathrm{mS} / \mathrm{cm}$ \\
\hline Accuracy & $2 \%$ of full scale & $+/-1 \%$ of full scale & $+/-0.5 \%$ of reading \\
\hline Operating Voltage & 10-30 VDC & 10-36 VDC & $10-36 \mathrm{VDC}$ \\
\hline Operating Temperature & $-5^{\circ} \mathrm{C}$ to $+55^{\circ} \mathrm{C}$ & $-10{ }^{\circ} \mathrm{C}$ to $+50{ }^{\circ} \mathrm{C}$ & $-5{ }^{\circ} \mathrm{C}$ to $+70{ }^{\circ} \mathrm{C}$ \\
\hline Warm-up Time & $3 \mathrm{~s}$ minimum & $5 \mathrm{~s}$ minimum & 3 s minimum \\
\hline Size of Probe & $3.2 \mathrm{~cm}$ diameter $\times 25.4 \mathrm{~cm}$ long & $3.8 \mathrm{~cm}$ diameter $\times 21.6 \mathrm{~cm}$ long & $22 \mathrm{~cm}$ diameter $\times 20.2 \mathrm{~cm}$ long \\
\hline
\end{tabular}

Figure 1 illustrates a schematic design of the LID approach with all the essential components to treat a contaminated wastewater site. The steps for site preparation are discussed in detail in [18], but briefly mentioned below:

i. $\quad$ excavation of existing soil up to $500 \mathrm{~mm}$ in depth;

ii. placement of impermeable membrane throughout the base;

iii. $\quad$ placement of Silva Cells ${ }^{\circledR}$;

iv. plantation of poplar trees within the Silva Cells with organic soil near tree roots;

v. filling the Silva Cells with gravel (clear crush)

vi. embedded $\mathrm{pH}$, turbidity and electrical conductivity sensors at the inlet of wastewater entering through a PVC pipe, as well as at the outlet of treated water;

vii. connection of all sensor cables to the data acquisition system;

viii. placement of GC pavers on top of the Silva Cells ${ }^{\circledR}$; and

ix. placement of perforated pipes at various intervals throughout the site.

After the site was prepared, the trees were irrigated on a regular basis to ensure strong bonding of roots with the surrounding soil for at least a couple of weeks. Following that, the wastewater effluents were allowed to be discharged through the LID setup. The sensors were programmed to record data on regular intervals both at entry and exit points that were automatically being uploaded to a web-based server using the WIFI connection via DAQ system.

The next section provides more details about the execution at a car wash site, followed by the analysis of the data recorded. 


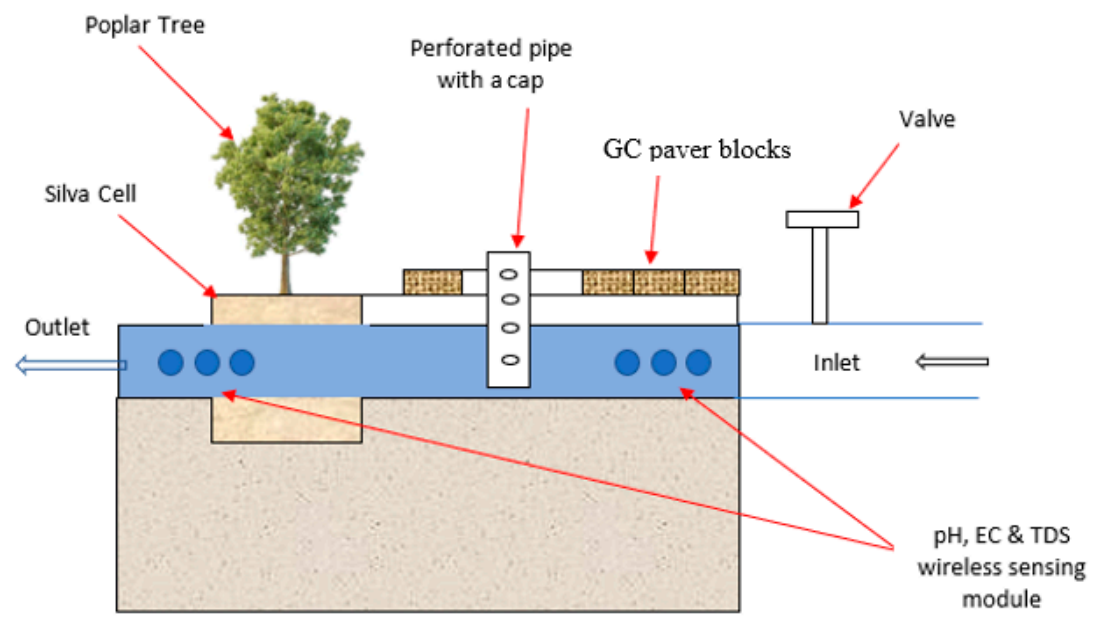

Figure 1. Schematic of proposed wastewater detoxification system at car wash site (cross-section view).

\section{Experimentation}

\subsection{Procurement and Nurturing of Poplar Trees}

Among trees, poplar (P. deltoides) are considered ideal plants for phytoremediation, as these can be propagated easily, grow quickly and are well adapted to a variety of climates. The first step included procurement of 50 tree saplings of $P$. deltoides from Bhola nursery, Jalandhar, India. The saplings were then transported to an agricultural field at Lovely Professional University (LPU) to evaluate its viability to plant at a car wash site. Initially, the growth of poplar trees was studied by planting them at a depth of 1.5 feet and $1 \mathrm{~m}$ apart from each other as shown in Figure 2.

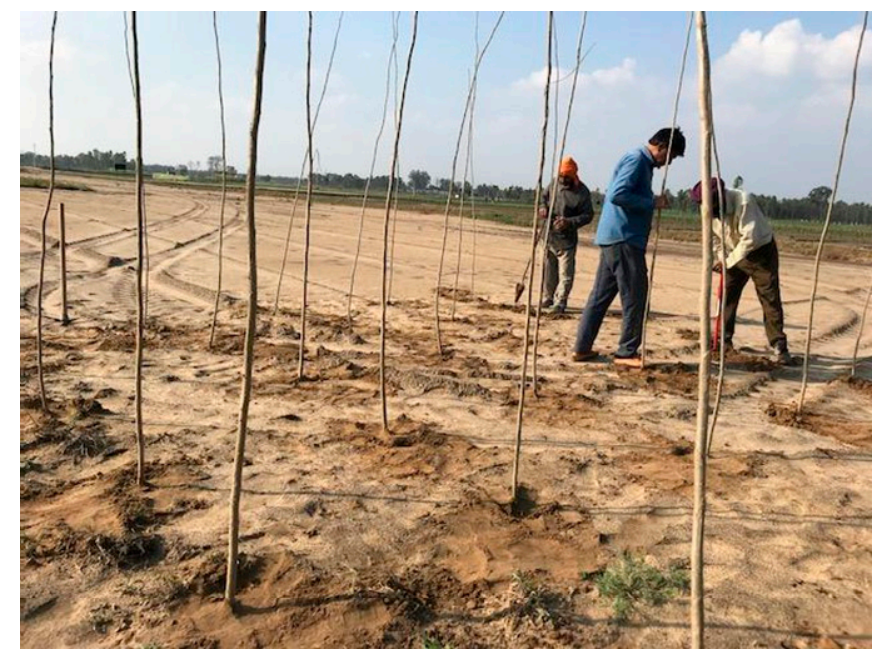

Figure 2. Planting of poplar trees at agriculture site (LPU).

The tree height was measured from the tip of tree to ground using a measuring tape. Diameter at breast height $(D B H)$ of the tree was calculated by creating a mark (at $1.37 \mathrm{~m})$ on tree trunk from the ground using measuring tape. A thread was then wrapped around that mark tightly and circumference was measured from the length of thread. The diameter was then calculated. For girth diameter, the circumference was measured at a certain height (approximately $0.6 \mathrm{~m}$ ) from the ground and the same procedure as in DBH measurement was followed.

$p H: \mathrm{pH}$ of the soil and water was measured by a digital $\mathrm{pH}$ meter, post calibration with buffer solutions of $\mathrm{pH} 4,7$ and 9. To measure soil $\mathrm{pH}, 20 \mathrm{~g}$ of soil sample was taken in a $100 \mathrm{~mL}$ beaker and $40 \mathrm{~mL}$ of distilled water was added. The mixture was stirred with a glass rod to uniformly 
mix the sample in water. It was then allowed to stand for half an hour with intermittent stirring. The electrode was immersed into soil water suspension in the beaker, and $\mathrm{pH}$ value was observed. Similarly, water $\mathrm{pH}$ was measured by taking the water sample and inserting a digital $\mathrm{pH}$ meter probe.

Electrical conductivity (EC): EC of the water and soil was also measured. For measuring EC of water, an EC meter was calibrated using a standard solution of known conductivity in calibration mode. The reading of standard solution was noted in the measuring mode to ensure the proper working of EC meter. Then the probe of conductivity meter was dipped into a water sample and reading was noted after the reading on display was stabilized. For measuring soil EC, similar calibration of the meter was done and then the probe was directly inserted into the soil and reading was noted.

Total dissolved solids (TDS): This important water quality parameter was measured using a digital TDS meter. The TDS probe was dipped into samples and readings were recorded. To estimate total suspended solids (TSS) in water, three conical flasks were taken and funnels were attached with Whatman filter paper. The methodology followed for the measurement of TSS in water was as per the ASTM D5907-18 Standard.

\subsection{Site Preparation for LID System}

The proposed wastewater treatment system was installed at a car wash site located at LPU, India. The average traffic at this site is 5-7 cars/day and around 200 to $250 \mathrm{~L}$ of water is used on a daily basis. Since this site was secure and no vandalism was expected, the team was able to deploy the above discussed LID system and real-time monitoring sensors for analyzing the quality of treated wastewater after dual filtration treatment. Figure 3 presents on-the-ground steps involved to prepare the site.

Firstly, a trench $8 \mathrm{~m}$ long, $0.8 \mathrm{~m}$ wide and $1.5 \mathrm{~m}$ in depth was dug adjacent to the washing area. The surface was fully covered with a polythene sheet so that water does not drain into the soil below. Secondly, Silva Cells ${ }^{\circledR}$ were placed in a trench where base plate of the cell along with posts were kept on the surface which was covered with polythene sheet. Thirdly, a total of six PVC pipes, three each on either side of the cells, were mounted in the trench to protect the sensors from any damage that may be caused due to aggregates. These pipes were mounted with a gap from the surface to allow the water to enter through it. Fourthly, the trench was filled completely with aggregates of size $10 \mathrm{~mm}$ and $20 \mathrm{~mm}$ to the level of posts and then, the top plate was placed. Further, six poplar trees were planted within the Silva Cells ${ }^{\circledR}$ and were filled with fertile soil (Vermicompost: Soil in 1:4 ratio). The whole cell area was covered with aggregates to provide maximum support and add weight. The aggregates provided greater water storage and contained the growth of poplar saplings to their designated sections. Following that, GC pavers made using industrial waste were placed on the top of Silva Cells ${ }^{\circledR}$ as described in Section 2.

The site was designed in a manner such that when wastewater after a car wash runoff through the surface, it passes over GC pavers and enters Silva Cells ${ }^{\circledR}$ via the drain system. In-order to be able to capture and record maximum data, the team decided to install the control real-time monitoring station approximately at the center of site as shown in Figure 3. DAQ system, i.e., HOBO RX3002 was placed in an enclosed locked chamber to mitigate vandalism and only allow authorized users to access it. The location of DAQ was perfect considering the $7.62 \mathrm{~m}$ long sensor cables that were installed both at inlet as well outlet of treated water. The three sensors for measuring $\mathrm{pH}$, turbidity and temperature, and electrical conductivity were inserted into PVC pipes, installed along the trench, and then connected to the DAQ system. These sensors were calibrated by using standard buffer solutions of their appropriate measurements. Once the sensors were identified by the DAQ system, it was then connected to WIFI for recording all physico-chemical parameters remotely onto the server. It should be noted that only LPU car washing site catered only light moving vehicles such as four wheelers and two wheelers 


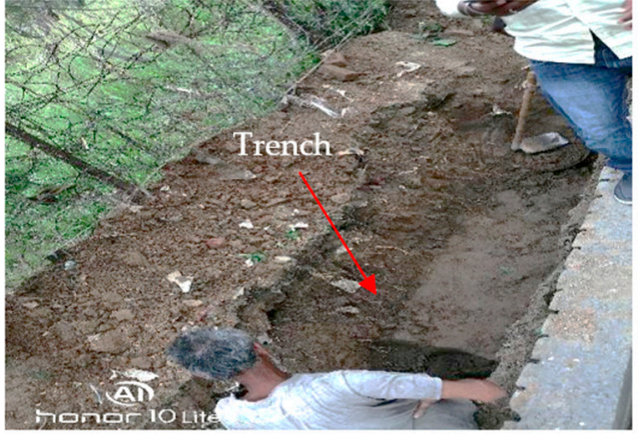

(a)

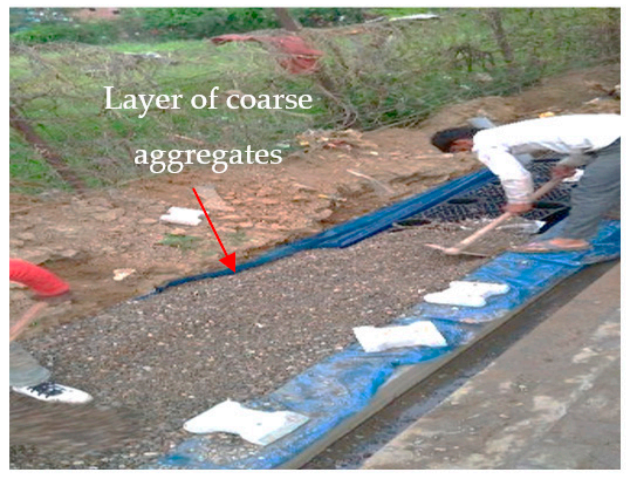

(c)

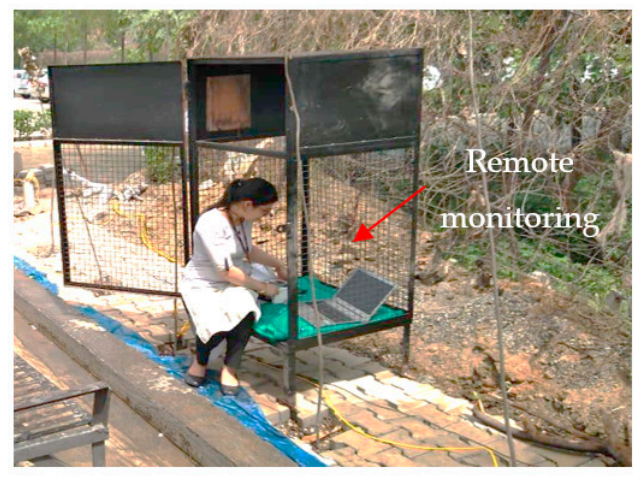

(e)

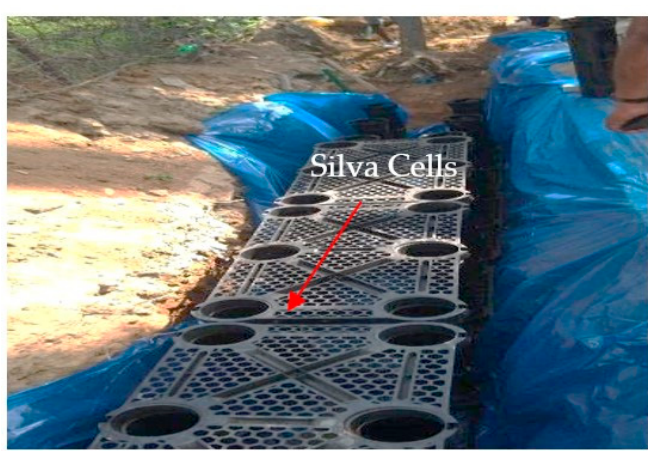

(b)

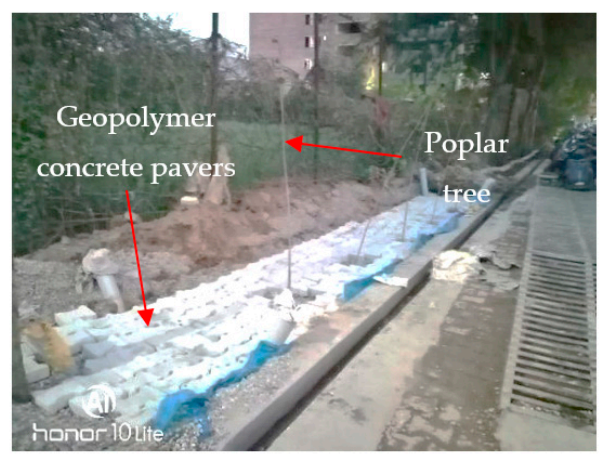

(d)

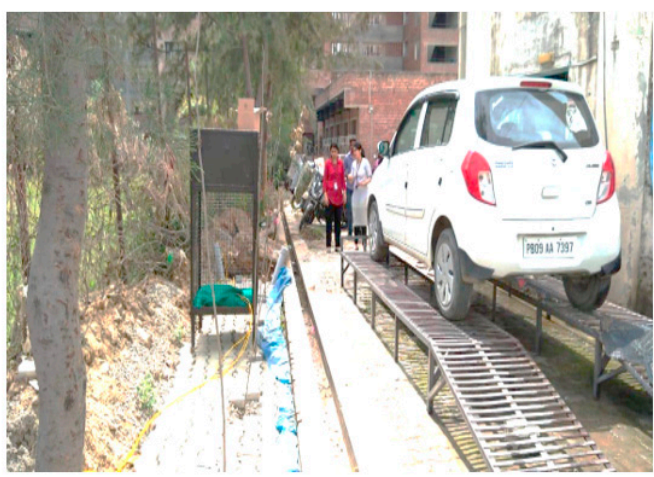

(f)

Figure 3. Step-by-step deployment of sensors in wastewater treatment system at LPU car wash site: (a) digging a trench of cross section $8 \mathrm{~m} \times 0.8 \mathrm{~m}$; (b) installation of Silva Cells ${ }^{\circledR}$ over a plastic sheet and plantation of poplar saplings; (c) filling of Silva Cells ${ }^{\circledR}$ with coarse aggregates of size 10-20 mm; (d) laying geopolymer concrete pavers over Silva Cells ${ }^{\circledR}$; (e) setting up a remote monitoring station for data collection; (f) general view of car wash site.

Site 2: After the successful installation at the LPU site, the team was able to identify and secure a commercial site, Mehat Car Wash service station, nearby for treating wastewater using this LID approach. After initial survey of the Mehat service station, the site layout was planned considering the natural outflow of water as demonstrated in Figure 4. Being a commercial facility, the team recorded higher average traffic on this site-about 15-20 cars per day with an approximate daily water consumption of 750-1000 L. The procedure followed for the second site preparation was similar to what the team had deployed at LPU site, as shown earlier in Figure 3. Briefly, a trench 5-m-long, $0.8 \mathrm{~m}$ wide and $1.5 \mathrm{~m}$ in depth was dug adjacent to the car washing area as presented in Figure 5. Four Silva Cells ${ }^{\circledR}$ were placed in the trench where base plate of the cell along with posts was placed on the surface. Five poplar trees were planted in the four Silva Cells ${ }^{\circledR}$ with one poplar tree in each of the first three cells 
and two trees in the last cell. Aggregates of size $10 \mathrm{~mm}$ and $20 \mathrm{~mm}$ to the level of posts were placed in remaining space in the trench and then the top plate was placed. A total of 3 PVC pipes were installed in the trench for the outlet of wastewater from the car washing area to Silva Cell bed. The whole cell area was covered with aggregates and a mix of fly-ash based GC pavers as well as normal concrete pavers. In order to allow the excess water to flow from Silva Cells ${ }^{\circledR}$, three PVC pipes of diameter 1 inch were inserted perpendicular to Silva cell bed as shown in Figure 5. The goal of Mehat car wash site is to analyze the efficacy of wastewater treatment system by inspecting the contaminants uptake by poplar trees that have been planted. Since no remote monitoring system was installed at this site, continuous data of physico-chemical parameters are not currently available. At Mehat car washing site, the traffic was a mix of heavy moving vehicles (tractors, double axel trucks etc.) and light moving vehicles (four wheelers and two wheelers).

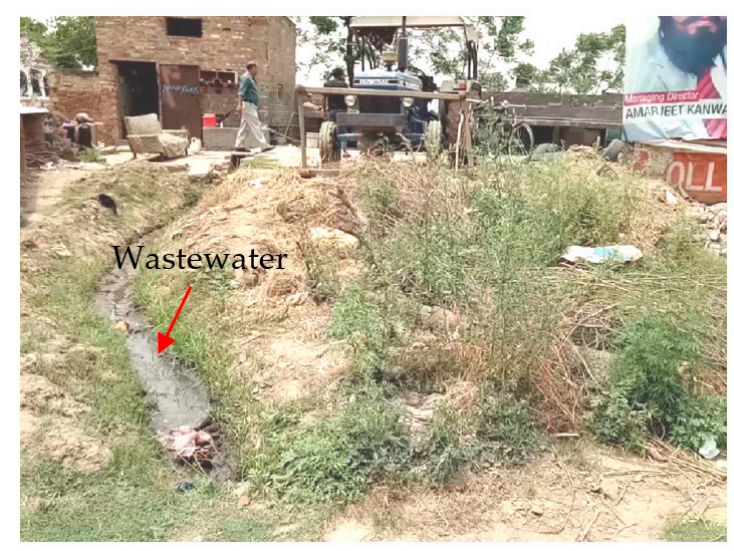

Figure 4. Car Wash Station at Mehat village in India: (a) place of installation of LID system; (b) car washing site.

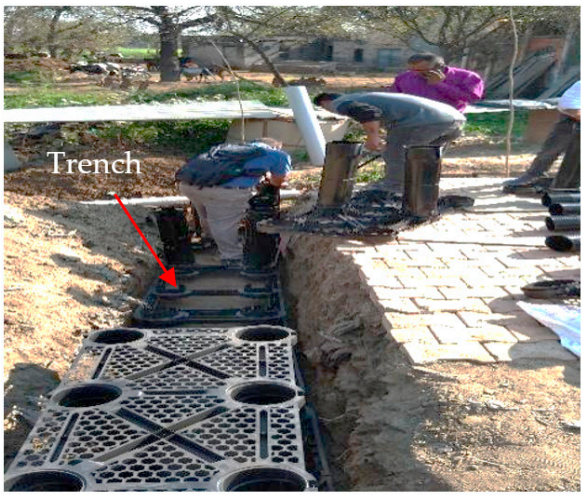

(a)

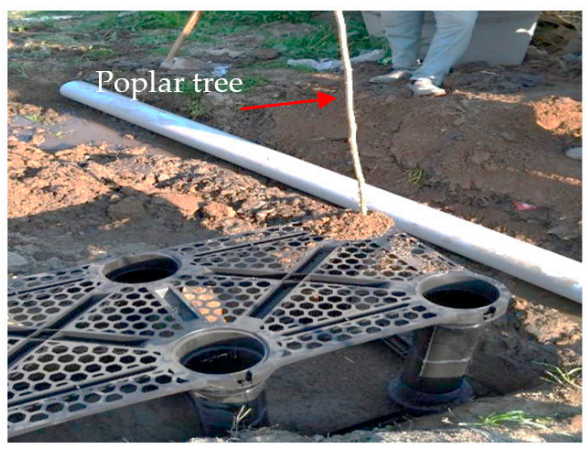

(c)

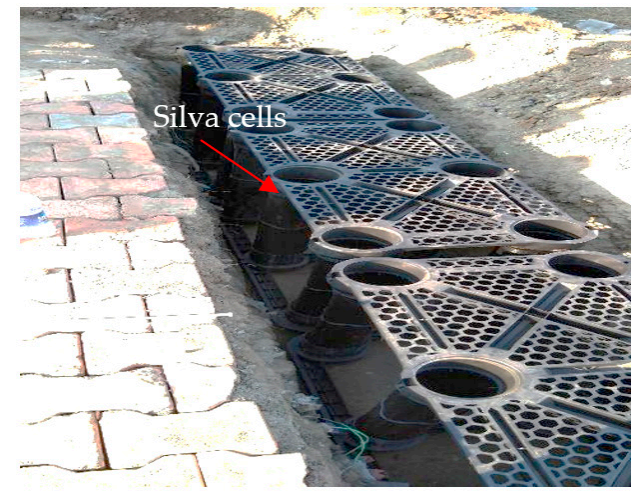

(b)

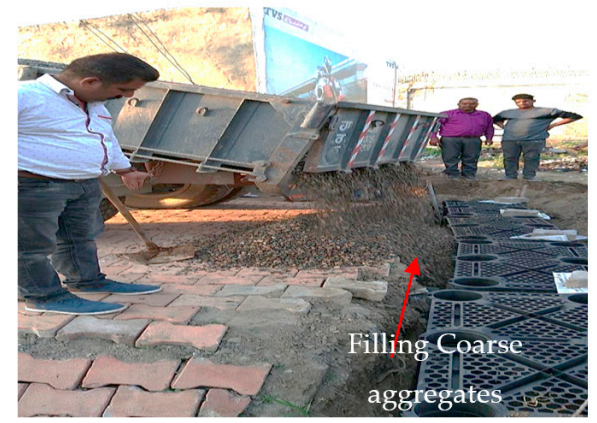

(d)

Figure 5. Cont. 


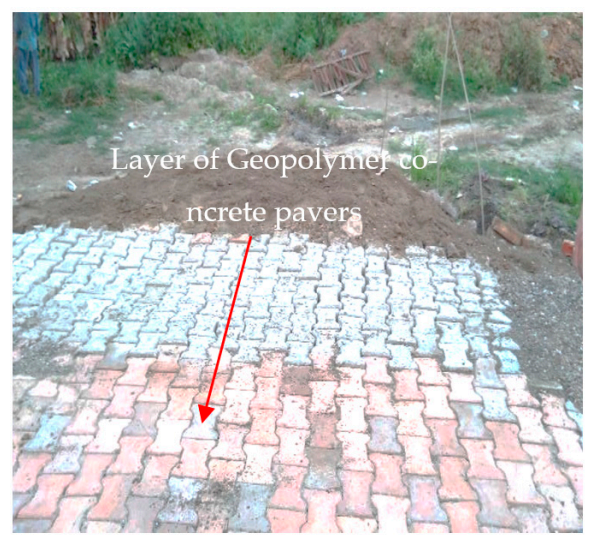

(e)

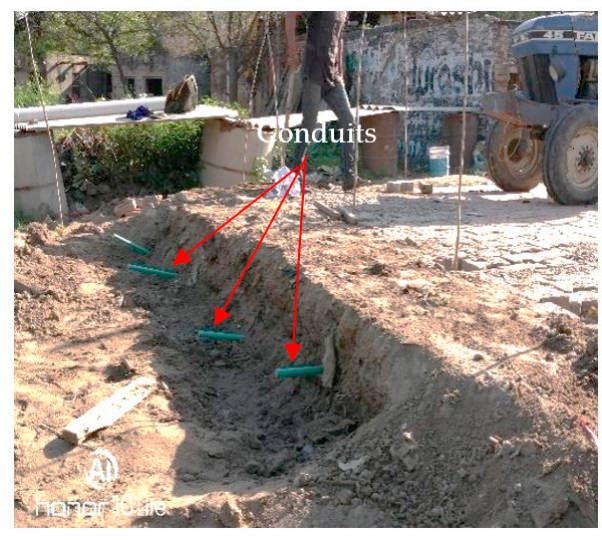

(f)

Figure 5. Step-by-step deployment of wastewater treatment system at Mehat car wash site: (a) creating a $5 \mathrm{~m} \times 0.8 \mathrm{~m}$ trench; (b) installing Silva Cells ${ }^{\circledR}$ in the trench; (c) planting poplar trees in the post of Silva Cells ${ }^{\circledR}$; (d) filling the entire trench with coarse aggregates ranging 10-20 mm; (e) laying geopolymer concrete pavers over the layer of Silva Cells ${ }^{\circledR} ;(f)$ installation of conduits for the outlet of treated wastewater.

\section{Results and Discussions}

\subsection{Growth Biometrics of Poplar Trees}

The poplar trees planted at the wastewater treatment system were compared with that planted in the agricultural field. The suitability of soil and water was analyzed at the time of plantation by checking $\mathrm{pH}$, TDS, and EC parameters, as shown in Table 3. The table shows that $\mathrm{pH}$ of soil and water at both sites is under permissible limit, which would not adversely affect the plant growth. The concentration of TDS in water for agricultural field and car wash site are within the permissible limit [26]. EC of soil and water was less than $1 \mathrm{mS} / \mathrm{cm}$ in both agricultural field and car wash site, which means soil and water are not saline and they are suitable for the growth of plants [27]. But, the EC of car wash water was more than that of agricultural field water, which may be due to the detergents and cleaning chemicals used in car washing.

Table 3. Measurement of $\mathrm{pH}, \mathrm{TDS}$, TSS and EC for soil and water analysis [26,27].

\begin{tabular}{cccccc}
\hline \multirow{2}{*}{} & \multirow{2}{*}{ Permissible Limit } & \multicolumn{2}{c}{ Agricultural Field } & \multicolumn{2}{c}{ Mehat Car Wash Site } \\
\cline { 3 - 6 } & & Soil & Water & Soil & Water \\
\hline $\mathrm{pH}$ & $5.5-8.5$ & 7.29 & 7.32 & 7.83 & 7.33 \\
\hline $\mathrm{TDS}(\mathrm{mg} / \mathrm{L})$ & 2000 & - & 267 & - & 381 \\
\hline $\mathrm{EC}(\mathrm{mS} / \mathrm{cm})$ & 1000 & 0.412 & 0.503 & 0.355 & 0.63 \\
\hline
\end{tabular}

Figure 6 shows the budding of leaves on poplar trees at agricultural field of LPU, India. Table 4 describes the biometrics of poplar trees planted at field site and car wash site. The parameters namely number of leaves, height of plants, number of branches, diameter at breast height, and girth diameter were compared at different time variance i.e., day $1,60,67,74$ and 81 . It was observed that poplar trees grew at a faster rate in field site conditions as compared to the car wash site. Existing studies reported the role of edaphic factors in the growth of plants [28] and hence organic and inorganic contaminants in the soil of car wash site might be attributed to impede the emergence of leaves and overall growth of poplar trees grown at car wash site. As a matter of fact, the roots of poplar trees are expansive in nature and require adequate air and water to spread. Nevertheless, the construction materials of car wash water treatment system could be impervious for the root network to expand during the acclimatization phase of the poplar plants in order to facilitate the growth of leaves. Furthermore, the coefficient of 
variation in the biometric parameters at day 81 was measured for the field and car wash site and observed greater variation in number of leaves (C.V. 140\%) and number of branches (C.V. 154\%) at car wash site. However, the height of poplar plants showed greater variation at field site (C.V. $4.89 \%)$ than car wash site, being in the ratio of 2.2:1. Similar pattern of greater variation in diameter (C.V. 14.8\%) and girth (C.V. 22\%) of poplar plants was observed at field site as compared to car wash site. Growth and development process in plants is controlled by extrinsic and intrinsic factors owing to the changes in plant metabolism. The overall growth of poplar plants at car wash site was slow as compared to field site which might be attributed to the presence of soil and water contaminants at car wash site and their accumulation in plants, resulting hampering growth of plants.

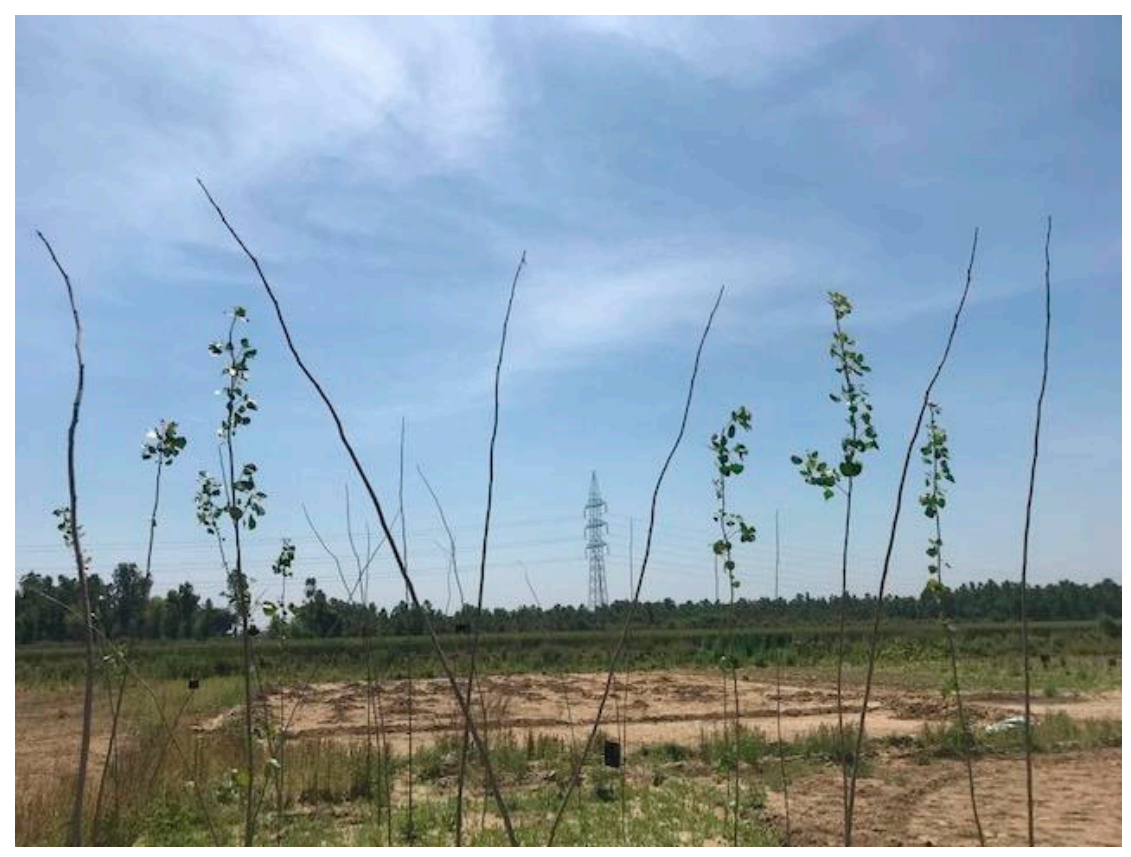

Figure 6. Poplar trees planted at agricultural field in India.

Table 4. Comparison of poplar tree biometrics on days 1, 60, 67, 74, and 81. Values of Mean \pm Margin of Error at the $90 \%$ confidence level are shown.

\begin{tabular}{|c|c|c|c|c|c|c|c|c|c|c|}
\hline \multirow[t]{2}{*}{ Parameter } & \multicolumn{2}{|c|}{ Day 1} & \multicolumn{2}{|c|}{ Day 60} & \multicolumn{2}{|c|}{ Day 67} & \multicolumn{2}{|c|}{ Day 74} & \multicolumn{2}{|c|}{ Day 81} \\
\hline & Field Site & Car Wash & Field Site & Car Wash & Field Site & Car Wash & Field Site & Car Wash & Field Site & Car Wash \\
\hline $\begin{array}{l}\text { Number } \\
\text { of leaves }\end{array}$ & 0 & 0 & $38 \pm 12.2$ & $30.4 \pm 3.8$ & $73.6 \pm 26.3$ & $30.6 \pm 32.3$ & $99.6 \pm 17.1$ & $45.8 \pm 47.0$ & $119 \pm 19.8$ & $52.8 \pm 54.4$ \\
\hline $\begin{array}{l}\text { Height of } \\
\text { plants } \\
(\mathrm{cm})\end{array}$ & $340 \pm 12.2$ & $343 \pm 6.8$ & $340.1 \pm 12.2$ & $343.2 \pm 6.8$ & $340.1 \pm 12.2$ & $343.2 \pm 6.8$ & $340.1 \pm 12.2$ & $343.2 \pm 6.8$ & $340.1 \pm 12.2$ & $343.2 \pm 6.84$ \\
\hline $\begin{array}{l}\text { Number of } \\
\text { branches }\end{array}$ & 0 & 0 & $14.4 \pm 8.6$ & $0.6 \pm 0.6$ & $14.6 \pm 3.3$ & $3.4 \pm 3.8$ & $16.8 \pm 0.9$ & $5.8 \pm 6.3$ & $15.8 \pm 2.5$ & $7.4 \pm 8.2$ \\
\hline $\begin{array}{c}\text { Diameter } \\
\text { at breast } \\
\text { height } \\
(\mathrm{cm})\end{array}$ & $0.67 \pm 0.07$ & $0.62 \pm 0.05$ & $0.67 \pm 0.07$ & $0.62 \pm 0.05$ & $0.67 \pm 0.07$ & $0.62 \pm 0.05$ & $0.67 \pm 0.07$ & $0.62 \pm 0.04$ & $0.67 \pm 0.07$ & $0.62 \pm 0.05$ \\
\hline $\begin{array}{c}\text { Girth } \\
\text { diameter } \\
(\mathrm{cm})\end{array}$ & $0.84 \pm 0.13$ & $0.68 \pm 0.03$ & $0.84 \pm 0.13$ & $0.68 \pm 0.03$ & $0.84 \pm 0.13$ & $0.68 \pm 0.02$ & $0.84 \pm 0.13$ & $0.68 \pm 0.03$ & $0.84 \pm 0.13$ & $0.68 \pm 0.03$ \\
\hline
\end{tabular}

\subsection{Physico-Chemical Parameter Analysis of Car Wash Water Pre-and Post-Treatment}

Data was collected at different time periods to evaluate the effect of Silva Cells ${ }^{\circledR}$, poplar trees and fly-ash based geopolymer concrete pavers on the treatment of car wash wastewater. The studies involved the analysis of physico-chemical parameters of tap water, inlet water entering through Silva Cells ${ }^{\circledR}$ and outlet water passing through Silva Cells ${ }^{\circledR}$. The LPU car wash site already shown in Figure 3 
was selected for water sample collection for analysis of physico-chemical parameters namely $\mathrm{pH}$, TDS and EC. Water samples were collected from three different locations of the car wash site viz. tap water used for car wash, wastewater entering the Silva Cells ${ }^{\circledR}$ prior to treatment, and outlet water from the last Silva Cell post treatment. Water samples were analyzed on the same day of collection for $\mathrm{pH}, \mathrm{EC}$ and TDS in the Water Laboratory of School of Bioengineering and Biosciences at Lovely Professional University following the standard protocol. The readings were verified with the real-time data recorded by DAQ system through sensors deployed at the site.

In Phase I of study, water samples were collected from April 2019 to August 2019 wherein tap water samples were control samples and water collected from the inlet of Silva Cells ${ }^{\circledR}$ were car wash water samples. These water samples were compared to determine the extent of pollution caused by organic and inorganic contaminants in car wash water. Figure 7a shows that $\mathrm{pH}$ of tap water ranges from 6.75-7.65 while $\mathrm{pH}$ of car wash wastewater ranges from 6.24-7.06. It was observed that $\mathrm{pH}$ of car wash wastewater is slightly less than tap water possibly due to the presence of nutrients and acidifying plant matter taken up by the vehicles traversing agricultural fields. Figure $7 \mathrm{~b}$ shows that EC of tap water varies from $503-580 \mu \mathrm{S} / \mathrm{cm}$ and that of car wash water varies from $560-653 \mu \mathrm{S} / \mathrm{cm}$. It was noted that electrical conductivity of wastewater was relatively greater than that of tap water indicating the presence of ions from salts and potentially heavy metals. Figure 7c compares TDS in tap water and car wash water. TDS of tap water was found to be $230-289 \mathrm{mg} / \mathrm{L}$ while that of car wash water was 282-342 mg/L. Further, no data was recorded between 19 June to 1 August. Generally, TDS of car wash water was greater than that of tap water, which is not surprising. There is one exception in which EC and TDS for the wastewater do not exceed that of the tap water and that is on 22 April.

In Phase II of this study, water samples were collected from December 2019 to early March 2020 wherein the car wash water entering through Silva Cells ${ }^{\circledR}$ prior to wastewater treatment and water at the outlet of the last Silva cell post wastewater treatment were compared. The comparison between pre- and post-treated water determines the efficacy of wastewater treatment system and is shown in Figure 8a-c. The proper growth of poplar plants was monitored simultaneously. The data of water quality parameters were also retrieved online on a weekly basis. Since the experiment on water collection and testing was conducted throughout the year, hence, a seasonal variation in the parameters was also observed.

The physico-chemical parameter readings shown in Figure 8 indicate that the water quality parameters such as $\mathrm{pH}$, TDS and EC of tap water, inlet water and outlet water, tested from December 2019 to early March 2020 were under the permissible limits as recommended by EPA [26,27]. In the present study, the highest increase in the level of EC and TDS was observed in the month of February, 2020 as compared to December, 2019 as shown in Figure 8, however the pH was found least affected by seasonal variation. Increasing trend in the level of EC and TDS was observed in the duration of the present study which was undertaken from December 2019 to early March 2020. EC determines the concentration of salts dissolved in water and capacity of water to conduct electrical current and therefore to the total dissolved solids which is a measure of inorganic salts and small amounts of organic matter. During summer season, with the increase in temperature, there is a concomitant increase in the amount of dissolved inorganic substances in ionic form and is attributed to increase in the level of EC and hence TDS, and low during winter season. EC and TDS are correlated and expressed in an equation wherein TDS $=\mathrm{kEC}$ at $25^{\circ} \mathrm{C}$ temperature [29]. Moreover, during summer season because of increase in temperature the conductivity of water increases which results in increase in ionic mobility. In addition, solubility of salts and many minerals in water also increases and is attributed to increase in TDS. 


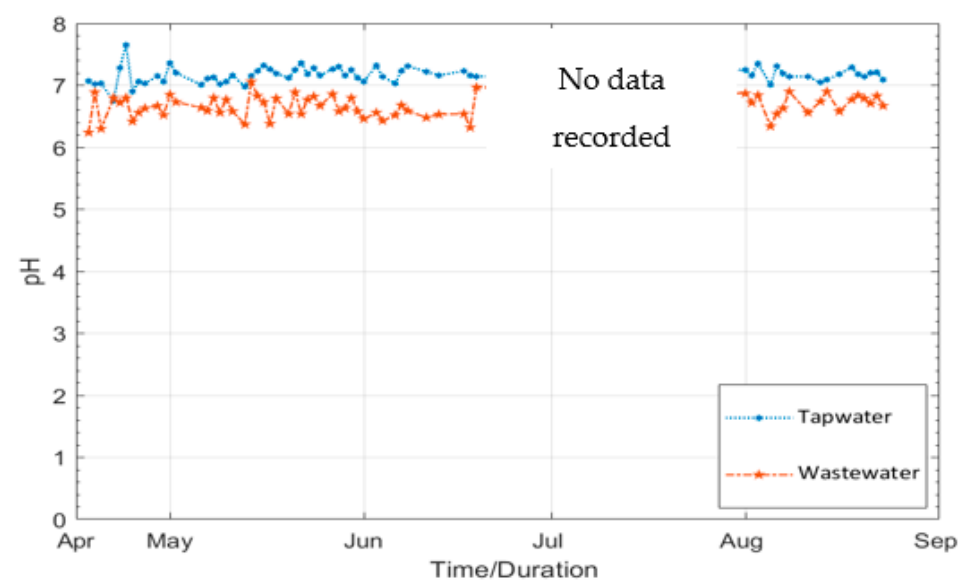

(a)

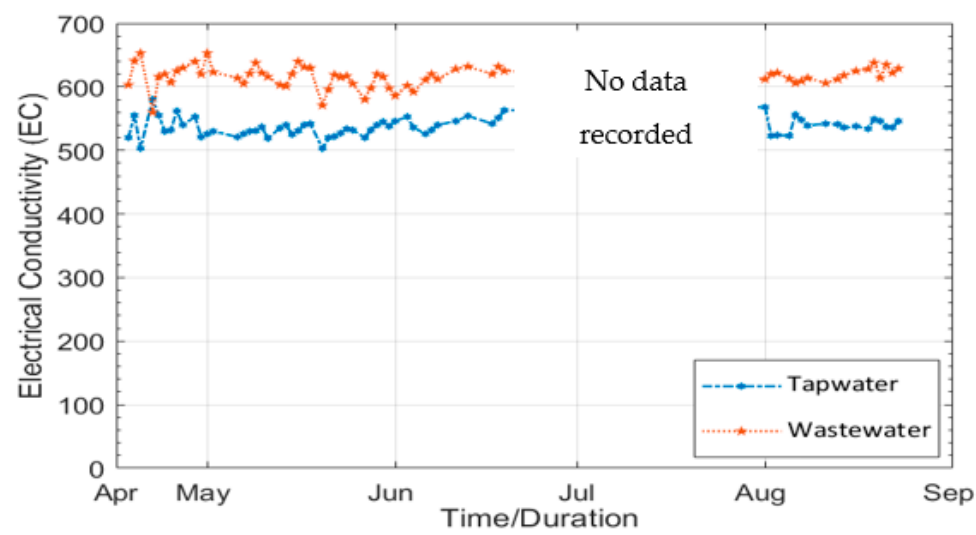

(b)

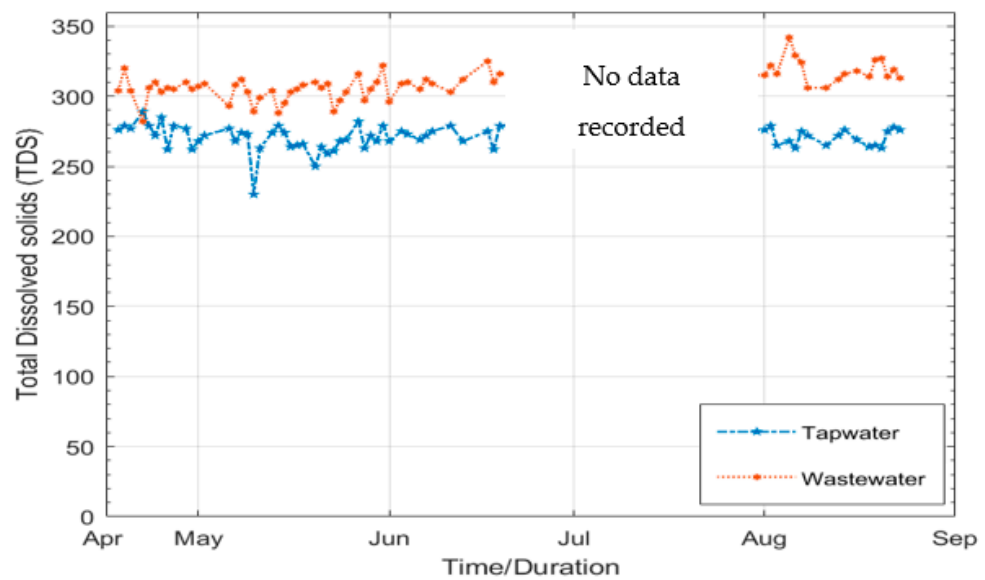

(c)

Figure 7. Comparison of tap water and wastewater entering Silva Cells ${ }^{\circledR}$ at car wash site for: (a) $\mathrm{pH}$; (b) EC; (c) TDS.

As indicated in Figure 8, present study is establishing the relation between EC and TDS so far the increasing pattern in the level is concerned under the influence of seasonal variation. The experimental 
data was consistent with the real-time monitoring data collected on the site. Further, the percentage change in TDS of inlet and outlet water was computed by the following formula.

$$
\text { Change in } T D S=\left[\frac{T D S_{\text {inlet }}-T D S_{\text {outlet }}}{T D S_{\text {inlet }}}\right] \times 100
$$

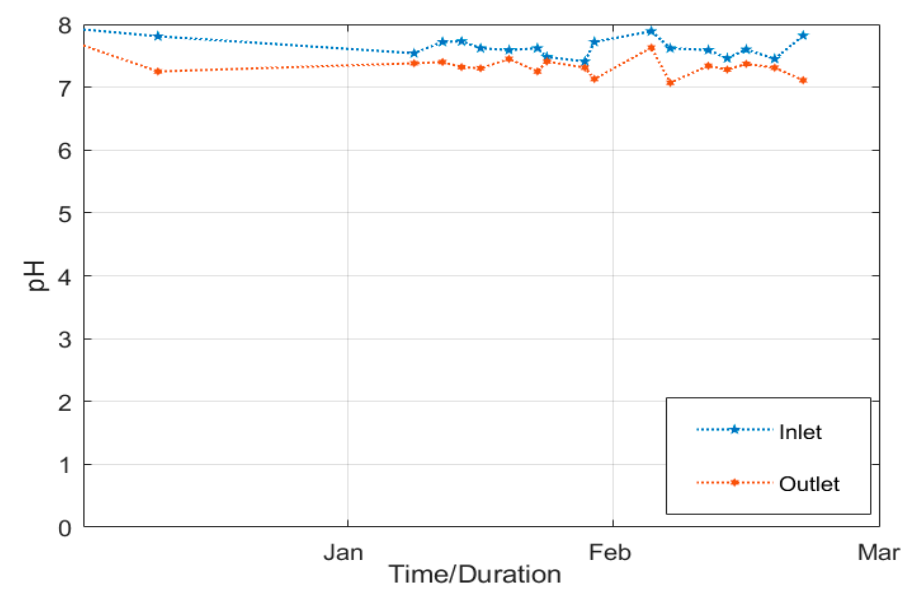

(a)

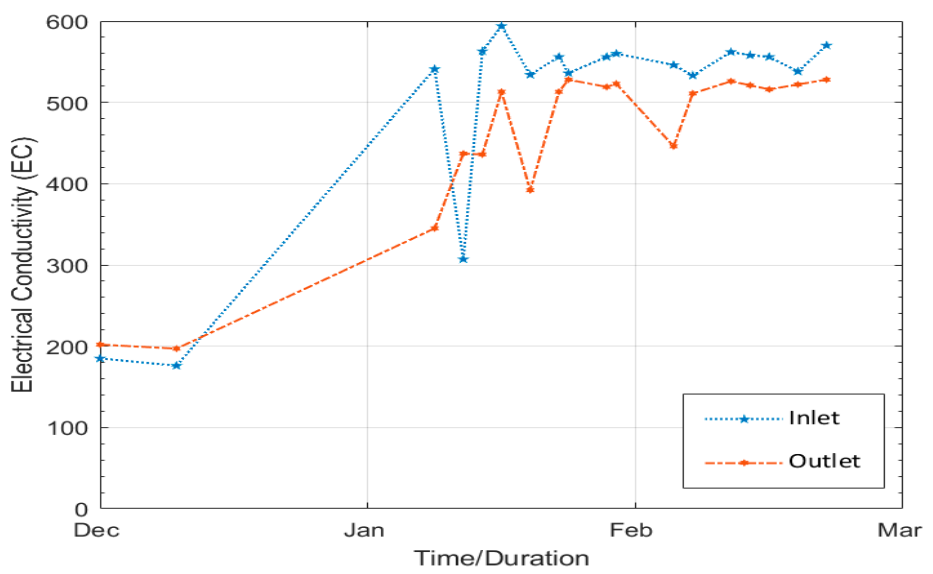

(b)

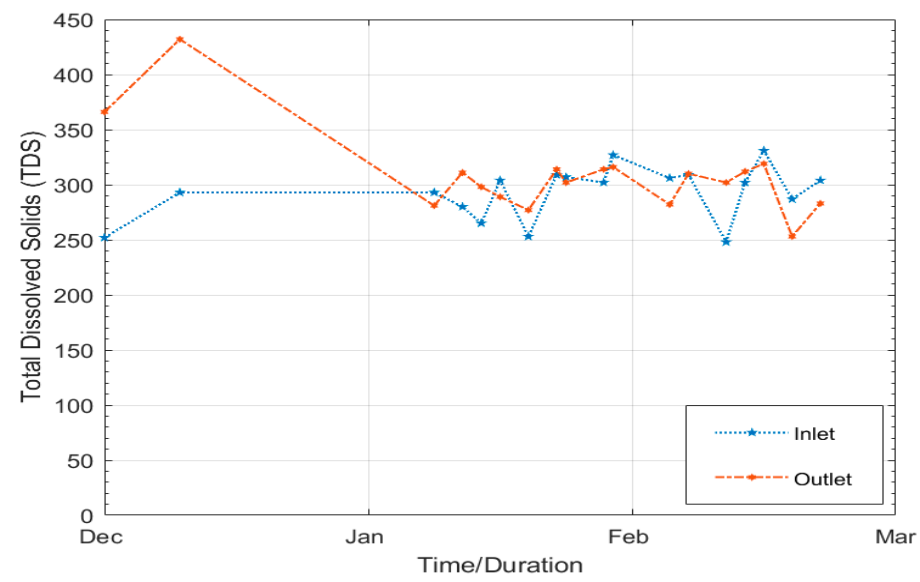

(c)

Figure 8. Comparison of car wash water at the inlet and outlet of Silva Cells ${ }^{\circledR}$ pre- and post- treatment respectively for: (a) $\mathrm{pH}$; (b) EC; (c) TDS. 
Figure 9 shows that the difference in TDS of inlet water and outlet water reduces over a period of time indicating the onset of decontamination of car wash water. Initially, a slight declivity in the curve is seen indicating that insignificant variation in recorded TDS values. This suggests that initial growth of poplar trees does not contribute in phytoremediation. This is succeeded by a sharp acclivity in the recorded variation of TDS values thereby indicating that after an initial growth, poplar trees contribute in wastewater treatment. The physico-chemical parameter analysis based on the selected initial data implies that the wastewater treatment system installed at car washing site is effective in reducing contaminants in the car wash water to reduce the effect of environmental pollution. As the root system of trees further develop and the trees mature, the effect of phytoremediation is expected to be further realized.

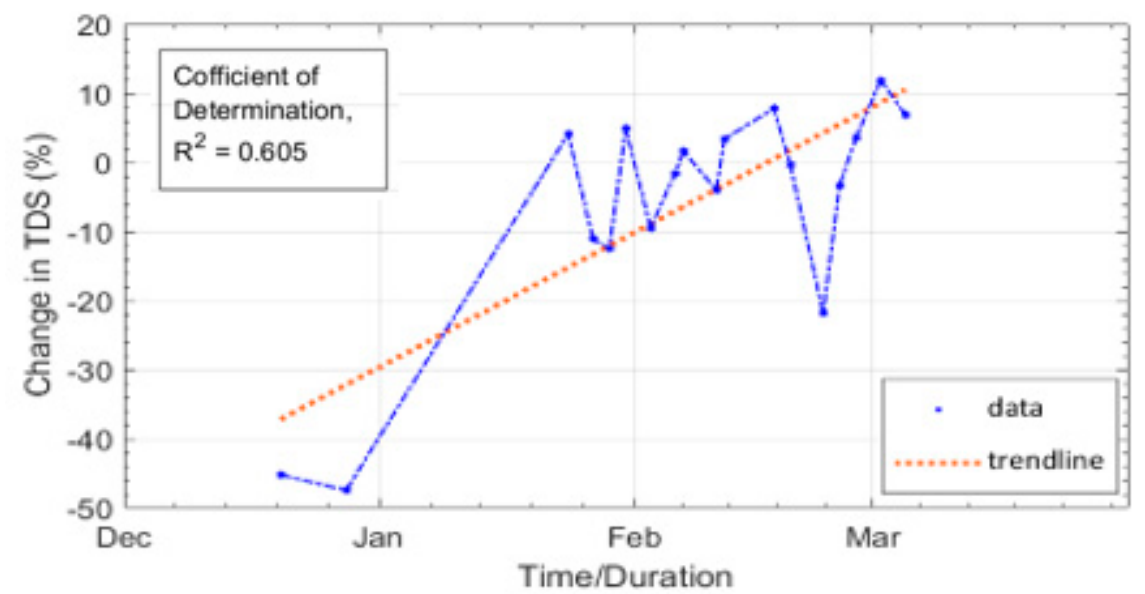

Figure 9. Percentage difference of TDS in car wash water at the inlet and outlet of Silva Cells ${ }^{\circledR}$.

\section{Summary and Conclusions}

This study established the potential for an in-situ eco-friendly waste-water treatment system which mainly relies on geopolymer concrete pavers that can infiltrate, Silva Cells ${ }^{\circledR}$, poplar trees, sensors and a remote monitoring station. Two different car washing sites were considered for the study. A multi-disciplinary set-up including a series of Silva cells for soil stabilization, cement-less pavers, Wi-Fi based smart sensing module for monitoring the efficacy of the system and poplar trees for phytoremediation. Soil and water analysis were performed beforehand to determine the suitability of planting poplar trees at car wash sites. The geopolymer concrete pavers constructed by utilizing the waste material from a coal thermal power plant proved to be an asset by making wealth from waste. A set of poplar trees collected from a local nursery, were analyzed by studying their biometric growth at agricultural field as well as a car wash site. Poplar trees planted at car wash site showed a delayed budding and lesser leaves and branches in comparison to poplar trees planted at the agricultural field. In spite of that, they contributed in the decontamination of wastewater over a period of time. The performance of wastewater treatment was evaluated by analyzing several physico-chemical parameters of untreated and treated water; specifically, $\mathrm{pH}$, Electrical conductivity and TDS. Sensors collecting these data were installed at the inlet of wastewater at Silva Cells ${ }^{\circledR}$ and the outlet of treated water from Silva Cells ${ }^{\circledR}$. An improvement in percentage change in TDS was observed post water treatment, proving the effectiveness of the hybrid eco-friendly technique for water reclamation. Furthermore, the entire technology including, cement free GC pavers, Silva Cells ${ }^{\circledR}$, and poplar trees can be highly economical as well as sustainable.

Author Contributions: Conceptualization, R.G., N.R.S., S.O.P. and C.V.; Data curation, A.S. and S.A.; Formal analysis, A.S. and S.A.; Funding acquisition, R.G., N.R.S., S.O.P. and C.V.; Investigation, N.R.S., A.S., S.A. and C.P.C.; Methodology, R.G., N.R.S., M.G., S.O.P., A.S. and S.A.; Project administration, R.G. and N.R.S.; Resources, R.G., N.R.S. and C.V.; Software, S.A.; Supervision, R.G., N.R.S., C.V., S.O.P. and C.P.C.; Validation, 
N.R.S. and A.S.; Visualization, A.S.; Writing—original draft, S.A.; Writing—review \& editing, R.G., N.R.S., C.V., M.G., A.S., S.A. and C.P.C. All authors have read and agreed to the published version of the manuscript.

Funding: This research was funded by India-Canada Centre for Innovative Multidisciplinary Partnerships to Accelerate Community Transformation and Sustainability (IC-IMPACTS), grant number UVIC 50203-52450.

Acknowledgments: The authors are thankful for the administrative and technical support provided by University of Victoria, Canada and Lovely Professional University, India.

Conflicts of Interest: The authors declare no conflict of interest. The funders had no role in the design of the study; in the collection, analyses, or interpretation of data; in the writing of the manuscript, or in the decision to publish the results.

\section{References}

1. Rajasulochana, P.; Preethy, V. Comparison on efficiency of various techniques in treatment of waste and sewage water-A comprehensive review. Resour.-Effic. Technol. 2016, 2, 175-184. [CrossRef]

2. Mo, J.; Yang, Q.; Zhang, N.; Zhang, W.; Zheng, Y.; Zhang, Z. A review on agro-industrial waste (AIW) derived adsorbents for water and wastewater treatment. J. Environ. Manag. 2018, 227, 395-405. [CrossRef] [PubMed]

3. Hoekstra, A.Y.; Chapagain, A.K. Water footprints of nations: Water use by people as a function of their consumption pattern. In Integrated Assessment of Water Resources and Global Change: A North-South Analysis; Craswell, E., Bonnell, M., Bossio, D., Demuth, S., Van De Giesen, N., Eds.; Springer: Dordrecht, The Netherlands, 2007; pp. 35-48. ISBN 978-1-4020-5591-1.

4. Joseph, N.; Ryu, D.; Malano, H.M.; George, B.; Sudheer, K.P. Anshuman Estimation of industrial water demand in India using census-based statistical data. Resour. Conserv. Recycl. 2019, 149, 31-44. [CrossRef]

5. Joshi, R.; Ahmed, S. Status and challenges of municipal solid waste management in India: A review. Cogent Environ. Sci. 2016, 2, 1139434. [CrossRef]

6. Water Pollution-India Environment Portal|News, Reports, Documents, Blogs, Data, Analysis on Environment \& Development|India, South Asia. Available online: http://www.indiaenvironmentportal.org. in/category/28/thesaurus/water-pollution/ (accessed on 20 April 2020).

7. Scheinberg, A.; Wilson, D.C.; Rodic-Wiersma, L. Solid Waste Management in the World's Cities; UN-Habitat: Washington, DC, USA, 2010; ISBN 978-1-84971-170-8.

8. Esplugas, S.; Gimenez, J.; Contreras, S.; Pascual, E.; Rodríguez, M. Comparison of different advanced oxidation processes for phenol degradation. Water Res. 2002, 36, 1034-1042. [CrossRef]

9. LaPara, T.M.; Alleman, J.E. Thermophilic aerobic biological wastewater treatment. Water Res. 1999, 33, 895-908. [CrossRef]

10. Bolto, B.; Dixon, D.; Eldridge, R.; King, S.; Linge, K. Removal of natural organic matter by ion exchange. Water Res. 2002, 36, 5057-5065. [CrossRef]

11. Mavros, P.; Daniilidou, A.C.; Lazaridis, N.K.; Stergiou, L. Colour removal from aqueous solutions. Part I. Flotation. Environ. Technol. 1994, 15, 601-616. [CrossRef]

12. Zouboulis, A.I.; Lazaridis, N.K.; Grohmann, A. Toxic metals removal from waste waters by upflow filtration with floating filter medium. I. The case of zinc. Sep. Sci. Technol. 2002, 37, 403-416. [CrossRef]

13. Khan, U.T.; Valeo, C.; Chu, A.; van Duin, B. Bioretention cell efficacy in cold climates: Part 1 - hydrologic performance. Can. J. Civ. Eng. 2012, 39, 1210-1221. [CrossRef]

14. Doty, S.L. Enhancing phytoremediation through the use of transgenics and endophytes. New Phytol. 2008, 179, 318-333. [CrossRef] [PubMed]

15. Pilon-Smits, E. Phytoremediation. Annu. Rev. Plant Biol. 2005, 56, 15-39. [CrossRef] [PubMed]

16. Arthur, E.L.; Rice, P.J.; Rice, P.J.; Anderson, T.A.; Baladi, S.M.; Henderson, K.L.D.; Coats, J.R. Phytoremediation-An Overview. Crit. Rev. Plant Sci. 2005, 24, 109-122. [CrossRef]

17. Khan, T.A.; Sharma, S.; Ali, I. Adsorption of Rhodamine B dye from aqueous solution onto acid activated mango (Magnifera indica) leaf powder: Equilibrium, kinetic and thermodynamic studies. J. Toxicol. Environ. Health Sci. 2011, 3, 286-297. [CrossRef]

18. Garg, M.; Valeo, C.; Gupta, R.; Prasher, S.; Sharma, N.R.; Constabel, P. Integrating natural and engineered remediation strategies for water quality management within a low-impact development (LID) approach. Environ. Sci. Pollut. Res. 2018, 25, 29304-29313. [CrossRef] 
19. Asha, M.N.; Chandan, K.S.; Harish, H.P.; NikhileswarReddy, S.; Sharath, K.S.; Liza, G.M. Recycling of Waste Water Collected from Automobile Service Station. Procedia Environ. Sci. 2016, 35, 289-297. [CrossRef]

20. Parametric Studies on Compressive Strength of Geopolymer Concrete-ScienceDirect. Available online: https://www.sciencedirect.com/science/article/pii/S1877705813000313 (accessed on 9 September 2020).

21. Gupta, R.; Rathod, H.M. Current state of K-based geopolymer cements cured at ambient temperature. Emerg. Mater. Res. 2015, 4, 125-129. [CrossRef]

22. Azarsa, P.; Gupta, R. Comparative Study Involving Effect of Curing Regime on Elastic Modulus of Geopolymer Concrete. Buildings 2020, 10, 101. [CrossRef]

23. Barac, T.; Weyens, N.; Oeyen, L.; Taghavi, S.; van der Lelie, D.; Dubin, D.; Spliet, M.; Vangronsveld, J. Field Note: Hydraulic Containment of a Btex Plume Using Poplar Trees. Int. J. Phytoremediation 2009, 11, 416-424. [CrossRef] [PubMed]

24. Clonal Variation in Survival and Growth of Hybrid Poplar and Willow in an IN SITU Trial on Soils Heavily Contaminated with Petroleum Hydrocarbons. Int. J. Phytoremediation 2005, 7, 177-197. [CrossRef]

25. Zalesny, J.A.; Zalesny, R.S.; Coyle, D.R.; Hall, R.B. Growth and biomass of Populus irrigated with landfill leachate. For. Ecol. Manag. 2007, 248, 143-152. [CrossRef]

26. EPA. Parameters of Water Quality: Interpretation and Standards; Environmental Protection Agency Ireland: Wexford, Ireland, 2001.

27. Indian Standard. Drinking Water-Specification, 1st Revision, IS 10500. 1991. Available online: https://www.google.com/search?client=firefox-b-d\&q=Indian+Standard\%2C+Drinking+water-specification\% 2C+1st+Revision\%2C+IS+10500+\%281991\%29 (accessed on 9 September 2020).

28. Berthelot, C.; Blaudez, D.; Leyval, C. Differential growth promotion of poplar and birch inoculated with three dark septate endophytes in two trace element-contaminated soils. Int. J. Phytoremediation 2017, 19, 1118-1125. [CrossRef] [PubMed]

29. Rusydi, A.F. Correlation between conductivity and total dissolved solid in various type of water: A review. IOP Conf. Ser. Earth Environ. Sci. 2018, 118, 012019. [CrossRef]

Publisher's Note: MDPI stays neutral with regard to jurisdictional claims in published maps and institutional affiliations.

(C) 2020 by the authors. Licensee MDPI, Basel, Switzerland. This article is an open access article distributed under the terms and conditions of the Creative Commons Attribution (CC BY) license (http://creativecommons.org/licenses/by/4.0/). 